\title{
Analysis on the Background and Historical Influence of the Party's Four Guarantees
}

\author{
Zehua Chen \\ College of Marxism \\ Wuhan University of Science and Technology \\ Wuhan, China
}

\author{
Muyun $\mathrm{Su}$ \\ College of Marxism \\ Wuhan University of Science and Technology \\ Wuhan, China
}

\begin{abstract}
At the moment of national crisis, the Communist Party of China put forward the "four guarantees" on the premise of "five demands" to the Kuomintang in the early 1937, reflecting the urgency of China's Anti Japanese war. After the Xi'an Incident, Jiang Jieshi and the Kuomintang government were also adjusting the policies toward Japan, and seriously preparing for the Anti Japanese. As the Communist Party of China put forward the "four assurances", the Kuomintang's domestic policy began a significant change, that Jiang Jieshi fully suspended the military action of the encirclement of the Red Army, marking that the Communist Party of China's "resisting against Japan combining with the KMT" took the first step. This paper argues that the proposal of the "four assurances" stopped the pace of the conflict between the Kuomintang and the Communist Party of China, and accelerated the pace of cooperation between the Kuomintang and the Communist Party of China, which not only had great historical significance, but also had great practical significance.
\end{abstract}

Keywords - the Communist Party of China; four guarantees; policy adjustment; cooperation between the Kuomintang and the Communist Party of China

\section{INTRODUCTION}

On the eve of the outbreak of the war of resistance, with the deepening of the national crisis, in order to promote the establishment of Anti Japanese National United Front, the Communist Party of China took the initiative to turn from the "Anti the KMT and Anti Japanese" to "resisting against Japan combing with the KMT". The Communist Party of China also called the Third Plenary Session of the Fifth KMT Central Committee in February 1937, put forward five requirements for cooperation between the Communist Party of China and the Kuomintang to resist against Japan, on this basis, to make the following four guarantees: (1) stop the armed overthrow policy of the Kuomintang government in the country; (2) the workers' and peasants' democratic government was renamed as the Republic of China Government, the Red Army was renamed as the National Revolutionary Army, directly subject to the guidance of Central Government in Nanjing and the Military Commission; (3) in the region of the SAR Government carry out the thoroughly democratic system of universal suffrage; (4) stop the policy of confiscating the land of the landlords, resolutely implement the common program of the Anti Japanese National United Front. Through the observation on the current situation, the KMT turn the policy to "the Anti Japanese", and basically accept the requirements put forward by the CPC, so that the second cooperation between the Kuomintang and the Communist Party of China formed the reform.

\section{THE BACKGROUND ANALYSIS ON THE COMMUNIST PARTY OF CHINA TO PUT FORWARD FOUR GUARANTEES}

\section{A. The Unprecedented National Crisis Confronted by the} Chinese Nation after the Nine One Eight Incident

After the Nine One Eight Incident, the Japanese occupied the northeast and made the northeast as its colony. From May to November, 1935, the Japanese made a series of events in North China. Under the threat of Japanese Imperialism, the Kuomintang government sent He Yingqin to negotiate with Japanese, and signed the Hemei Agreement. This agreement made the entire military, politics and economy in Hebei under the control of Japanese Imperialism. Subsequently, the KMT was forced to sign the Qintu Agreement, which made China lose the majority of sovereignty in Chahar.

Japanese Imperialism had stepped up its economic aggression while military aggression against North China. On the one hand, the plunder of the natural resources of North China especially munitions resources is just like that the later scholars pointed out in the relevant documents: "prior the outbreak of the Lugouqiao Incident, if we carefully observe Japanese active action in plundering and hijacking China's various resources and industries, the outbreak of the war is expected earlier.". On the other hand, the crazy commodity dumping in the North China and other places, not only made our country's national economy suffer heavy losses, but also made the people's life deteriorate sharply. First, the miserable life of the working class, industrial disasters, increased the number of casualties. As "at that time a song spread among miners 'one hundred yuan down, one thousand and three hundred pennies up'. That is to say when the miners went down the wells, they had the determination to die so that their families could get 100 yuan of pension; if the well water and gas did not ruin them, they only got low wages of one thousand and three hundred pennies". Second, the rural economy was pressed seriously, the famine continued widespread, and farmers' life got worse. Prices of agricultural products were squeezed and exploited by Japanese and foreign 
businessmen, plus disasters occurred frequently, farmers could barely survive.

As the North China Incident occurred, the Chinese nation came to the critical moment of life and death, the contradiction between imperialism and the Chinese nation officially rose as the principal contradiction in our society.

\section{B. The Observation on the Current Situation by the Communist Party of China}

1) The survival predicament confronted by the Central Committee of the Communist Party of China after arrived in the north of Shaanxi: On the 25000 Li Long March Road, the survival condition were very bad, the Red Army soldiers had to endure the coldness and hunger at the same time, ready to prepare for entering the spirit of fighting, resulting in many Red Army soldiers buried in the snow mountain and grassland.

In October 1935, the Central Committee of the Communist Party of China arrived in the north of Shaanxi Province to successfully join forces with the First Route Army of the Red Army and the Fifteenth Army of the Red Army, giving a heavy blow to the KMT. The Kuomintang immediately adjusted the "encirclement and suppression" deployment, personally commanded to take the strategy of attacking the south and blocking the north, to implement a full range of Red Army offensive. At the critical moment, the Central Military Commission elaborately planned, uniformly commanded, organized fierce battle and finally broke through the enemy attack. In October 1936, the First Route Army, the Second Route Army, the Fourth Route Army of the Red Army successfully jointed forces in Huining, totally saving the power of more than 30 thousand people. The drastic reduction of personnel, the inside and outside attack of the hostile forces, made the Central Committee of the Communist Party of China in the more dangerous predicament, which also provided more difficult challenges for the Communist Party of China to get rid of containment of the Kuomintang, undertake the mission of resisting Japan and saving the nation.

2) The Northwest Joint led to the transformation of the policy of armed struggle: After the Communist Party of China carried out the strategy deployment in order to establish the Anti Japanese National United Front, to realize the national war of resistance, began to try to establish a joint with the Kuomintang's part of the patriotic army. From January to April 1936, through the efforts, the Communist Party of China reached agreement successively with Zhang Xueliang and Yang Hucheng on the establishment of the Anti Japanese National United Front. Since then, the Northwest Army led by Yang Hucheng and the Northeast Army led by Zhang Xueliang officially joined the Anti Japanese camp, forming the three major joint of the Red Army, the Northwest Army and the Northeast Army.

The trinity of "Northwest Joint" was a major change in the armed struggle strategy of the Communist Party of China, and it was a reflection of the rise of national contradiction in the struggle strategy of the Communist Party of China. The object of armed struggle was no longer the "class enemy" in the country, but the foreign national enemy. The Northwest Joint was not only a necessary preparation for forcing Jiang Jieshi to resist Japan, but also a practical demonstration of the Communist Party of China's "stop armed uprising against the Kuomintang" and the adaptation of the workers and peasants to the Red Army.

\section{The Peaceful Settlement of the Xi'an Incident Is the Time Window to Put Forward the Four Guarantees}

Zhang Xueliang and Yang Hucheng to oppose Jiang Jieshi's civil war policy, was forced to launch the worldshaking Xi'an Incident. After the incident, it caused a strong reaction in the country. After being informed of the $\mathrm{Xi}$ 'an Incident, the Central Committee of the Communist Party of China immediately held a meeting, and decided to help the peaceful settlement of the Xi'an Incident from the perspective of the interests of the nation, to achieve the peaceful situation of "resisting against Japan combining with the KMT". At the same time, the CPC sent representatives to Xi'an to carry out talks for many times, and discuss the solutions with Zhang and Yang. Eventually, they reached an agreement with Nanjing Government. Jiang Jieshi agreed to stop the civil war and commonly resist Japan, also invited Zhou Enlai to Nanjing for direct negotiations. Subsequently, Zhang and Yang released Jiang Jieshi, and Xi'an incident was peacefully resolved. Since then the time window of the four guarantees put forward by the CPC opened.

\section{The Adjustment of Domestic and Foreign Policies of the KMT after the Nine One Eight Incident}

After the Nine One Eight Incident, the domestic and foreign policies of Jiang Jieshi experienced the transformation from focusing on "maintaining internal security" to "maintaining internal security and repelling foreign invasion", then to "repelling foreign invasion". Firstly, Jiang Jieshi attempted to quickly destroy even the Communist Party of China, to achieve national stability and unity, enrich national strength, and then carry out of "repelling foreign invasion". After the Nine One Eight Incident Jiang Jieshi wrote in the diary: "after heard that Shenyang, Changchun, Yingkou were occupied by Japan, I was so uneasy and grieved as if I lost my parents. I felt so ashamed of being the descendant of my ancestors. If not to recover the northeast, I will never have human dignity."But this policy led to failure of maintaining the domestic security and uprising of foreign aggression due to the setback of anti communist military, making the national crisis gradually deepened, and receiving the widespread blame. Jiang Jieshi swayed between the anti CPC and anti Japanese, that continued concessions to Japanese Imperialism at the same time, speeded up the preparation for the anti Japanese of national defense construction, paid equal attention to maintaining internal security and repelling foreign invasion. After the Japanese Imperialism made a series of incidents in North China, Jiang Jieshi pursued his promises to basically agree with the further peace talk with the CPC. At that time Jiang Jieshi realized the importance of "repelling foreign invasion", namely on the one hand, the pressure of public opinion at home and abroad; on the other hand, the aggravating crisis situation that touched Jiang Jieshi's national feelings. In the peace talks, the KMT and the CPC basically reached a consensus of "united to resist the enemy". The 
process of negotiation was exactly an important manifestation that Jiang Jieshi attached great importance to "repelling foreign invasion".

\section{E. The Guidance of the Communist International Policy}

After the establishment of the CPC, in a long time the CPC had been very dependent on the Communist International. This kind of dependence led to the invasion of the frequent errors of dogmatism and empiricism within the Party. The Communist International even sent commissioner directly to guide the Chinese revolution. Until the CPC Central Committee held a meeting in Zunyi in 1935, through the rectification and solutions of internal problems, the basically straightened out the relationship between the Communist International and the Communist Party of China. In the next "Anti the KMT and Anti Japanese" and "resisting against Japan combing with the KMT", the CPC Central Committee began to dialectically treat the guidance of the Communist International.

On the eve of the outbreak of the war, the ethnic conflicts had been developed to the suffering point, the KMT and the CPC had come to the situation that non unity could not resist the enemy. The Communist Party of China was experiencing a painful transformation suffering. In January 1937, the Secretariat of the Communist International Executive Committee called the Central Committee of the Communist Party of China, and suggested a fundamental change in Soviet revolution policy. Therefore, the Central Committee of the Communist Party of China called the Third Plenary Session of the Fifth KMT Central Committee in February, and put forward the implementation of "five requirements" and "four guarantees" for cooperative anti-Japanese between the Chinese Communist Party and the Kuomintang. From the content, the Central Committee of the CPC although had made major concessions, but this concession was necessary for the realization of cooperation between the KMT and the CPC, and it was not without conditions, reflecting the growing maturity of the CPC in dealing with the relationship between the KMT and the CPC of seeking truth from facts and independence.

\section{THE HISTORICAL INFLUENCE OF THE FOUR GUARANTEES PUT FORWARD BY THE CPC}

\section{A. Accelerate the Adjustment of Domestic and Foreign Policies of the Kuomintang}

After the Third Plenary Session of the Fifth KMT Central Committee, although it did not determine the Anti Japanese policy, the fact that the KMT's policy had begun to change was undeniable. The main performance of its policy adjustment is as follows.

In the domestic policy, the policy of "encirclement and suppression" to the CPC was changed to the principles of "peaceful reunification", and started cooperation and negotiations with the CPC. At the same time, after the outbreak of the war, Jiang Jieshi established the national political committee to widely adopt the social speech, to make it as the proceedings of the Anti Japanese War, so that the democratic process of the KMT's ruling had been rapidly promoted. Therefore, the proposal of the four guarantees laid the foundation for the multi-party cooperation, the extensive and deep development of the democratic movement in the eight years of war. The situation of the Kuomintang's one party dictatorship began to be changed.

In the foreign policy, after the Third Plenary Session of the Fifth KMT Central Committee, Jiang Jieshi firstly proposed the idea of comprehensive anti Japanese, and decided to take the following three measures. Firstly, organize the combat troops, with 100 divisions for the first line, 80 divisions for the auxiliary forces, secretly establish the stronghold and the headquarters of each group army and legion before the end of July. Secondly, accumulate two thirds of the existing ammunition of six months amount in the north of the Yangtze Rive and one third in the south of the Yangtze River. If the arsenal were blown up by the enemy, buy arms from France and Belgium, and ensure to ship back to China via Hong Kong and Vietnam route. Thirdly, prepare 1 million soldiers, 500 thousand warhorses and supplies of six months. These three measures were the emergency measures to prevent Japanese further expanding its aggression against China. Jiang Jieshi also started to take a tougher foreign policy on the issue of Japan. On international issues, he sent the Finance Minister Kong Xiangxi to seek assistance from the UK and the United States, also sent Song Ziwen to contact with the Soviet Union to discuss cooperation matters. The foreign policy of the Kuomintang began the initiative of full range, to create a favorable international environment for the upcoming total resistance.

\section{B. Promote the Rapid Adjustment of the Policy of the Communist Party of China}

With the proposal of the four guarantees, the Kuomintang basically accepted the proposal of the CPC Central Committee on cooperation between the KMT and the CPC, so as to basically realize the domestic peace. In order to adapt to the new situation, the CPC Central Committee accelerated the adjustment of the policy on the basis of the four guarantees.

- In the military, the Communist Party of China changed the class struggle to the national struggle, from the civil war to the war of resistance against Japan; changed the strategy of quick battle to the protracted war of resistance; changed the movement war to guerrilla war, and raised the guerrilla war to a strategic position; developed the regular army combat to the national anti Japanese war. The proposal of the four guarantees promoted the army of civil war quickly into an army to resist the invasion, which laid the foundation for the military of the Anti Japanese National United Front.

- In power, in order to fulfill the promises of "renaming and system reform" in the four guarantees, the Communist Party of China renamed the Office of the CPC Central Committee for the Border Region Government, changed the workers and peasants democracy to Democratic Republic. The CPC also gave up the idea of the establishment of the Democratic Republic of Workers and Peasants, and 
admitted the leadership of the National Government in fact.

- In the agricultural issues, the most fundamental was to solve the problem of land. The basic policy of the CPC Central Committee for the land issues during the period of anti Japanese war was adjusted to the land policy of reduction of rent and interest. The reduction of rent and interest was the concrete realization of the policy to stop confiscation landlord's land in the rural, which reduced the landlord exploitation of farmers and united part of the landlords. It effectively promoted the economic construction in the resistance bases, laid the economic foundation for the Anti Japanese National United Front.

\section{The Communist Party of China has Won the Understanding and Support of the Masses}

The proposal of the four guarantees was the significant concessions and sacrifices for the realization of national independence made by the Communist Party of China. According to the situation at that time, the establishment of the Anti Japanese National United Front was in line with the requirements of the people of all ethnic groups and the overall interests of the Chinese nation. And the CPC's efforts to achieve this goal, not only made the CPC become the mobilization power of the national awareness, but also guided the direction of public opinion. As a result, the social credibility of the Communist Party of China had also been rapidly promoted, and gained the advocacy and support of more people.

The four guarantees of the Communist Party of China were the correct policies and guidelines put forward in the deepening course of the national crisis. Because it always strove for the liberation of the Chinese nation in the first place, fundamentally maintained the common interests of the people of all ethnic groups, and carried out active action on the basis, thus it gradually obtained the understanding and support of the people of the country from all walks of life. The political position of the Communist Party of China was established, which laid the social conditions for the victory of the Anti Japanese war.

\section{Accelerate the Establishment of the Anti Japanese National United Front}

After the proposal of the four guarantees, the Kuomintang basically accepted the five requirements proposed by the Communist Party, which laid the foundation for the further peace talks between the KMT and the CPC, accelerated the establishment of Anti Japanese National United Front

On the one hand, the Communist Party's concessions, laid the foundation for further negotiations between the two parties. On the basis of the concessions, Jiang Jieshi and the CPC had several rounds of negotiations around the reorganization of the Red Army, the cooperation forms of the two parties, the status of the Shaanxi-Gansu-Ningxia border region etc. and finally reached a consensus. With the efforts of the CPC, in September 1937, the Kuomintang Central Committee announced the Declaration of the KMT - CPC Cooperation, acknowledged the CPC's legal status and the necessity of the national salvation. So far, the Anti Japanese National United Front of the cooperation between the KMT and the CPC was formally established.

On the other hand, the Communist Party's concession to the Kuomintang was established in a certain principle. If gave up the leadership like that in the period of the first cooperation between the KMT and the CPC, it would only lead to the bursting of the Anti Japanese National United Front. Therefore, only in certain principles to make concessions to ensure the political leadership of the proletariat and its political party, the domestic peace and democracy can be achieved, the Anti Japanese National United Front can be quickly established.

\section{REFERENCES}

[1] Mao Zedong Anthology, People's Publishing House, 1991 edition.

[2] Zhang Xiuzhang, Jiang Jieshi Diary Secret (volume 2), United Press, 2007 edition.

[3] The Reference Materials of the History of the CPC, volume 7, compiled by the Party History Teaching and Research Section of Chinese People's Liberation Army Politics Institution, 1979 edition.

[4] The CPC Central Committee Document Anthology, Beijing: the CPC Central Party School Publishing House, 1985 edition.

[5] Since Its 6th Congress, compiled by the Secretariat of the Central Committee of the CPC, People's Publishing House, 1981 edition. 